\title{
THE EFFECT OF PHYSICIANS' GENDER AND EXPERIENCE ON PERSIAN MEDICAL INTERACTIONS
}

\author{
Fariba Ramazani Sarbandi, Giti Taki, Pakzad Yousefian \\ and Mohamad Reza Farangi
}

\begin{abstract}
This study focusing on physician-patient interactions aimed to find out whether physicians' gender and experience influence Persian doctor-patient interactions. So power strategies in physician-patient interactions were extracted and categorized to explore the relationship between physicians' gender and experience and power strategies. Fieldwork was conducted in clinics and hospitals of Rafsanjan city in Iran. One hundred physician-patient consultations were audiotaped and transcribed during 2011-2012. Woods' (2006) view was used to examine four strategies of power and knowledge on their talk. The findings pointed out the importance of investigating discourse of medicine in order to improve medical consultations, especially physician-patient interactions. Our study confirmed some previous assertions that physician-patient interactions were asymmetrical. Physicians controlled and dominated the medical consultations by questioning, interruptions, directive statements and tag questions. The analysis of the data revealed that all power strategies were applied in Iranian physician-patient interactions. The results of Chi-Square tests indicated that there was a significant relationship between power strategies and physicians' experience and gender. It was concluded that the female and inexperienced physicians tended to control consultations by questioning, interruption, directives and tag questions more than the male and experienced physicians.
\end{abstract}

\section{Keywords}

gender, experience, questioning, interruption, directive statement, tag question

\section{Introduction}

Physician-patient interaction has been a topic of great interest to research in the medical fields and discourse analysis. In the last thirty years, studies on talk and interaction have increasingly been focusing on specialized forms of human activities, often within particular organizational or institutional settings. A very productive area of investigation is the study of doctor-patient interaction, which has caught the interest of sociologists, anthropologists, psychologists, and linguists (Cirillo 2005: 2). Doctor-patient interaction has received considerable attention since the early 1950s (ibid.: 6).

Several studies have highlighted the discourse of medicine, especially physician-patient interactions. Physician-patient interaction is attracting an 
increasing amount of attention within health care and linguistics studies. Descriptive and experimental research works have recently studied the communication process during medical consultations.

Physician-patient interaction is an example of discourse that shows a special distribution of power and knowledge and is composed of two classes: professional and non-professional. Woods (2006: 120) claimed that there is an asymmetrical distribution of power between the doctor and the patient; he likened spoken exchanges of medical consultations to the legal language that is constructed according to particular communicative routines, often realized in ritualized language, and reflects an asymmetrical distribution of power.

Discourse is language plus context, or real language in use. According to Woods (ibid.: x) the term 'discourse' is used for 'language in use' - the real language that real people use in the real world, it refers to the fact that language is very much more than just the sum of the linguistic elements that compose it. Discourse is language plus context that includes our experiences, assumptions and expectations and changes our relationship with others.

There are different approaches to discourse analysis, one of which is critical discourse analysis (CDA). CDA focuses on the social and ideological functions of language in producing, reproducing or changing social structure, relations and identities. It concerns the linguistic realization of power. Simpson and Mayr (2010: 51) argue that "CDA also incorporates social theoretical insights into discourse analysis and its practitioners are often outspoken about their social commitment and interventionist intentions."

The word "critical' signals a departure from the more descriptive goals of discourse analysis where the focus has been more on describing and detailing linguistic features than on why and how these features are produced. A critical approach to discourse, typically, analyzes news texts, advertisements, political interviews or other so-called 'unequal' encounters. These encounters often employ linguistic strategies that appear normal and neutral on the surface, but may, in fact, be ideologically invested. The term 'critical' therefore principally means unraveling or denaturalizing ideologies expressed in discourse and revealing how power structures are constructed in and through discourse (ibid.)

In other words, Schmidmast (2004: 354) suggested that in terms of social standing most physician-patient interactions are encounters among unequal sides: the physician usually has a higher socio-economic status than the patient. Moreover, a physician can behave more or less dominantly during the medical visit, which either enhances or attenuates existing dominance differences between him/her and the patient. 
Regarding this point, Barnet (2006: 3) asserted that the communication relationship was very asymmetrical in that patients looked to doctors similarly as children do in a parent-child relationship. Doctors assumed the parental role of 'knowing what was best' in order to care for the patient.

\subsection{Theoretical framework}

The theoretical framework of this study is Woods' (2006: 114-155) 'discourse of medicine'. Woods (2006: xiv) followed Fairclough, van Dijk and Wodak's theory; the interdisciplinary analytical perspective known as 'critical discourse analysis' seeks to examine language as a form of cultural and social practice, and is an approach which allows the description and interpretation of social life as it is represented in talk and texts. Woods believed that the critical approach aims to challenge social orders and practices that are accepted as 'natural', but are, in fact, 'naturalized'; it makes visible the 'common-sense' social and cultural assumptions or ideologies.

Woods (ibid.: 121) looked at the discourse of medical consultations and examined how doctors and patients typically sequence and organize their language in the context of medical interviews and how language reflected the asymmetrical distribution of power in the doctor-patient relationship. The following section presents four power strategies which Woods suggested.

First, questions play an important role in the structure of doctor-patient interaction, which is important for both the doctor and the patient as a means of exchanging information. Woods (ibid.: 135) indicated that medical consultations between doctors and patients are similar to an interview; and claimed that, unsurprisingly, the structure of medical discourse is a question-and-answer format that is a tried and tested device and gives us a clue toward the nature of the sort of discourse we are looking for. The question-and-answer device clearly depends on a presupposition that suggests who asks questions and who is answered by choosing the careful words.

Let us consider how the doctor manages the organization of interaction in the following example of a medical interview.

(1) Patient: hello, // doctor: hello, thanks, what's seems to be the problem? // Patient: I have a cold. // Doctor: is there sore throat and cough? // Patient: yes, I feel burning in my tonsils. // Doctor: do you have sore throat, is it burning? // Patient: yes, I have fever and chills. // Doctor: you should take Antibiotics. // Patient: my stomach gets bothering from it. // Doctor: Amoxyclav and Syfyksym cause stomachache, so Azithromycin should be taken. If you're bothered, you should take a stomachache pill as well, I'll prescribe a syrup for coughs. 
Woods (2006: 143) verified that questions frequently function as a powerful discourse device, controlling the sequencing of speaker turn as well as restricting the topic of response and the ensuing interaction; it allows the questioner (doctor) to control the sequence of who speaks and when, and also to manage the content or topic of what is spoken about.

Second, Woods (ibid.: 145) revealed that doctors' power reflects on their consultation by interrupting the patients' speech. His research showed that patient contributions are frequently interrupted by doctors, with one analysis showing almost 70 per cent of patients' initial statements of concerns being interrupted, usually by narrowly focused, closed-ended questions.

The following example demonstrates the controlling interruption by the doctor.

(2) Doctor: What's the problem with you? Patient: A few months ago, there were dandruff in my son's hair, we visit a doctor then they were disappeared (removed), now it starts ag... (continuing explanation) Doctor: Okay, how old is he? Patient: 7 years old.

Third, Woods (ibid.: 149) indicated that the doctor takes control over the interview by using a directive statement in his/her declaration as he/she can say you have to give up smoking; this reflects the doctor's powerful position over the patient and implies that the doctor has more knowledge about the patient's circumstances.

Gyuró (2014: 4) also claimed that questions and directives used by the doctor have the sole purpose of making the patients express their feelings in the situation. Therapeutic interviews can be divided into two types: directive and non-directive. These different approaches to interviewing involve different linguistic peculiarities in the interaction between doctors and patients. Let us examine the directive statement in the following example.

Doctor: I'm going to examine your mouth. Open your mouth wide for me. Let me put these tongue blades under your lips to look from side to side. Stick your tongue out. Lift it up to the roof of your mouth... down again ... to your right ... to your left.

Context of the medical branch forces doctors to use many directives really frequently (ibid.: 12).

Fourth, Woods (ibid.: 147) highlighted that tag questions can be used as controlling devices that typically present a proposition in declarative, noninterrogative form, with a yes/no-question tagged on to the end. Harres (1998) discussed the use of tag questions in medical interviews and found that tag 
questions can also function as expressions of empathy. They function as a powerful discourse device in the courtroom.

Tag questions are short questions consisting of an auxiliary (don't, isn't) and a pronoun (it, you) added to the end of a statement. They are used more often by women when expressing opinions. These features of women's speech all seem to be ways of inviting agreement with an idea rather than asserting it (Yule 2010: 279).

In this regard, Thompson (2009: 4) suggested that tags are used for different purposes, one of which is to seek for confirmation. Consider the following two examples.

(4) Doctor: What do you mean by "feeling sick"? Of course that sounds a bit vague, doesn't it? Feeling squeamish? Patient: Yes, not really squeamish, that I would have to vomit. It's just cramps.

(5) Doctor: It's the right side that bleeds more, isn't it? Patient: Yes.

Regarding the physician's power and dominance, the importance of this study mostly lies in the fact that these strategies which reflect the physician's power in physician-patient interactions have not been studied in Persian yet. Due to such significance, the researchers conducted an investigation to extract and categorize power's strategies in physician-patient interactions and find their relationship with the physician's gender and experience.

In order to obtain the aim, we set out to study physicians and patients interactions within our regional community, Rafsanjan city in Iran. Our purpose was to examine medical consultations between physicians and patients to see how physician's gender and experience affect the asymmetrical talk. To analyze this, one hundred physician-patient consultations were audiotaped in clinics and hospitals of Rafsanjan city in Iran.

The following research questions were proposed based on Woods' discourse of medicine (2006: 118-155).

1. Is there any relationship between questioning and the physician's gender and experience?

2. Is there any relationship between interruption and the physician's gender and experience?

3. Is there any relationship between directive statements and the physician's gender and experience?

4. Is there any relationship between tag questions and the physician's gender and experience? 
To our best knowledge, it should be mentioned that our research represents the first work on Persian medical consultations. We hope that our findings will be useful for linguistics studies and health policy making.

\section{Review of literature}

Many research studies have been performed to study physician-patient interactions to find the degree of power and dominance asymmetry between physicians and patients. The specific areas of research on physician-patient interaction relevant to our study are: gender, experience, questioning, interruption, directive, and tag question.

As mentioned earlier, the local studies in this issue are limited in Iran. A research by Hashemi (2002: 1) investigated physician-patient discourse from the critical discourse analysis view. Her study's title was The Reflection of Power Relationship on Physician-Patient Discourse. Hashemi considered nonlinguistic variables such as gender, age, social status and education, and concluded that power is reflected on the physician-patient discourse.

Several studies have been conducted on doctor-patient encounters analyzing the linguistic and discursive peculiarities occurring in these interactions, more important of which are outlined in the following paragraphs.

Rhoades et al. (2001) examined physician-patient communication patterns and interruptions in communication. Their findings revealed that numerous interruptions occurred during office visits and gender was associated with the patterns of interruptions. They reported that both female and male physicians interrupted female patients more than male patients.

Roter et al. (2002) assessed facilitative phrases with questions tags such as 'isn't it?' and 'don't you?' Their study reported significantly higher use of the question tag 'don't you?' by females compared with male physicians but the question tag 'isn't it?' did not show a significant gender effect.

Ohtaki et al. (2003) investigated communication patterns of doctor-patient consultations in two different cultures, namely the USA and Japan. They wanted to elucidate linguistic differences and similarities in communication. They examined the ratios of questions, explanatory and directive statements and other speech acts in doctor-patients' encounters. The proportions of physician versus patient total speech acts were 55 per cent and 54 per cent, respectively in the USA, and 59 per cent and 41 per cent in Japan. In both countries directive statements had a physician versus patient ratio of 19/1. This ratio confirmed the physicians' power over the asymmetrical talk.

In another research, Schmidmast (2004) conducted a study on physicianpatient interactions to find the degree of dominance asymmetry between 
physicians and patients. He concluded that female physicians adopted a less dominant interaction style with their patients than male physicians did by including their patients in decision making, eliciting their patients' concerns, experiences, norms, and values, asking for their patients' opinion, not interrupting their patients and treating their patients with respect.

Li et al. (2004) in their study examined effects of physician's age, gender and number of years in the profession on the way they interrupted and were interrupted. Their findings indicated that the female patients exhibited eleven times more cooperative interruption than the male patients. When the physicians interrupted their patients, they were unsuccessful only in six per cent of the cases. When the patients interrupted the physicians, they were unsuccessful in 32 per cent of the times. The physicians interrupted more intrusively and with more success while the patients interrupted more cooperatively and with less success. The discrepancy between physicians and patients in their rates of unsuccessful interruptions is five per cent vs. 32 per cent; in addition, Li et al. (ibid.) also concluded that there was a positive correlation between the physician's age, the number of years of being a physician and professional satisfaction, but no significant correlations were found between the physician's age, the number of years in profession, and their interruption patterns.

Kunsmann (2005) investigated whether gender or status and power are the motivating force for conversational behavior. He reported that participants use a number of strategies to achieve their conversational goals. His research proposed that two of the controlling mechanisms in micro-institutions are related to the strategy of interrupting and the use of tag questions. He revealed that men interrupt more often than women; male dominance could be established and female physicians were interrupted more often by patients of all social status groups compared to male physicians. Women used this type of questions more often than men, so female dominance could be established.

Li et al. (2007) also conducted another study and revealed that physicians controlled the medical consultations by asking more questions than patients, and patients did not necessarily appreciate this type of communication. Their study indicated that physician-patient interactions were highly asymmetrical. They concluded that physicians asked more questions than patients did ( $89 \%$ vs. $11 \%$ ).

Černý (2007) analyzed the function and character of speech acts in doctorpatient interactions and suggested that the roles and functions of speech acts indicated the asymmetrical relationship between doctors and patients. These acts are usually classified into five categories: namely declarations, representatives, expressives, directives, and commissives. 
In another research, Černý (2010) focused on a selected number of functions carried by the employment of interruptions. Its findings reflected the tendency towards a more balanced character of doctor-patient interviewing. Černý believed that both interactants were very active interrupters, with slight numerical dominance on the part of the doctor. Both the doctor and the patient interrupt each other throughout the medical encounter and take the advantage of all the functional types of interruptions.

Heritage (2010) studied the effects of questions on patients' responses. A central finding was that these effects were pronounced and generally exceeded the significance of other more contextual factors such as patient and health care provider characteristics, medical practice, social attitudes, and other less proximate characteristics of the medical visit. Their questions were unavoidably communicative. He verified that the grammatical polarity of the question, which favoured a yes response, was aligned to the objective of the question, which was the hope of obtaining free medication. However, a question with the same objective could have been designed with negative polarity (e.g. you don't have any samples, do you?). This format grammatically respected the recipient's right to reject the request and embodies negative politeness. The action was designed for a yes, but its grammatical format was designed for a no. The choice between aligned and cross-cutting preferences is a key resource through which physicians communicate, and patients apprehend the communication of information in questioning.

Jefferson et al. (2013) found out that the female physicians adopted a more partnership building style and spent on average 2.24 min longer with the patients per consultation ( $95 \%$ CI $0.62-3.86$ ) than their male colleagues. In addition, the female physicians showed lowered levels of dominance during consultations and a more submissive tone of voice towards the end of a consultation. The female physicians appeared to engage in more rapport building behaviors such as encouragement, reassurance, lowered dominance and positive talk and may also exhibit more affective behaviors such as concern, empathy and sympathy.

In another research, Gyuró (2014) indicated that questions and directives used by the doctor have the sole purpose of making the patient express his/ her feelings in the situation. The doctor used a directive to make the patient speak about his/her problem, reduce his/her anxiety about the new situation, and clarify the purpose of the interview. Using a directive, the doctor showed his/her interest towards the patient and gave the patients the freedom to express their own thoughts and feelings.

Along with many research studies mentioned above, our study tried to examine whether the physician's gender and experience (the number of years 
in the profession) have an effect on asymmetrical talk between physicians and patients through four strategies introduced by Woods (2006): questioning, interruption, directives, and tag questions. The study aimed to find out whether Persian physicians' dominance and control is reflected in their consultations by use of the strategies.

\section{Methodology}

This section provides a presentation of the participants and instruments that were utilized for the study and a description of the method which was used for the analysis.

\subsection{Participants}

The participants of the study include ten physicians classified into two groups, five male and five female physicians; five physicians had an experience of more than five years in the profession (experienced) and five physicians less than five years in the profession (inexperienced). One hundred patients visited these ten physicians in their practices, each physician visited ten patients individually and of one hundred patients, 32 patients were males and 68 females. The age of the participants was not considered. They were selected randomly. Their consultations took place at the clinics and Hospitals of Rafsanjan in Iran during 2011-2012. The conversations were audio-recorded in the physician's office.

\subsection{Instruments and procedure}

Audio-recording was used in the study. After the physicians agreed, the physicians-patients' interactions during the consultations were audio-recorded. The patients were not informed that the consultations would be audiotaped to maintain normal reactions. The patients' consent was obtained at the end of the consultations. All the patients were given an introduction about our research and they all agreed that their interviews could be part of our investigation. The recording of consultations was approved by University of Medical Science, Rafsanjan, Iran. The recorded audio consultations were repeatedly listened to and all the data were transcribed in detail. Each transcription was analyzed according to Woods' power strategies and the frequency of each item was identified and counted in 100 medical interactions. The obtained data were analyzed using SPSS software version 20 to compare the possible relationship between the physicians' gender and experience and power strategies. 


\section{Results and discussion}

The main objective of this study was to explore the relationship between the physician's experience and gender with the frequency of his/her power strategies. The results are presented in the following tables.

\begin{tabular}{|l|l|l|l|l|}
\hline $\begin{array}{l}\text { Power strategies } \\
\text { (gender, experience) }\end{array}$ & 1-Questioning & 2-Interruption & $\begin{array}{l}\text { 3-Directive } \\
\text { statement }\end{array}$ & 4-Tag question \\
\hline 1- Female Inexperienced & 55 & 12 & 16 & 23 \\
\hline 2-Female Experienced & 46 & 10 & 20 & 21 \\
\hline 3-Female Experienced & 19 & 6 & 11 & 10 \\
\hline 4-Male Inexperienced & 10 & 3 & 15 & 2 \\
\hline 5-Male Experienced & 22 & 5 & 15 & 7 \\
\hline 6-Female Inexperienced & 41 & 12 & 20 & 18 \\
\hline 7-Male Experienced & 68 & 9 & 20 & 12 \\
\hline 8-Female Inexperienced & 46 & 8 & 42 & 15 \\
\hline 9-Male Experienced & 20 & 5 & 24 & 4 \\
\hline 10-Male Inexperienced & 25 & 6 & 19 & 6 \\
\hline
\end{tabular}

Table 1: The frequency of power strategies in 100 doctor-patient interactions

The first research question explored the relationship between power strategies and the physician's gender and experience. The results showed that there is a statistically significant relationship between questioning and the physician's gender.

$\{\mathrm{H} 0$ : There is a relationship between questioning and the physician's gender

H1: There is not a relationship between questioning and the physician's gender

Count

\begin{tabular}{|ll|r|r|r|}
\hline & & \multicolumn{2}{|c|}{ Gender } & \multirow{2}{*}{ Total } \\
\cline { 3 - 4 } & & male & female & \\
\hline \multirow{2}{*}{ questioning } & No & 218 & 376 & 594 \\
Total & Yes & 125 & 220 & 345 \\
& & 343 & 596 & 939 \\
\hline
\end{tabular}

Table 2: Questioning * gender crosstabulation 


\begin{tabular}{|c|c|c|c|c|c|}
\hline & Value & df & $\begin{array}{l}\text { Asymp. Sig. } \\
\text { (2-sided) }\end{array}$ & $\begin{array}{l}\text { Exact Sig. } \\
\text { (2-sided) }\end{array}$ & $\begin{array}{l}\text { Exact Sig. } \\
\text { (1-sided) }\end{array}$ \\
\hline Pearson Chi-Square & $.021^{\mathrm{a}}$ & 1 & .886 & \multirow{6}{*}{.944} & \multirow{6}{*}{.471} \\
\hline Continuity Correction $^{\mathrm{b}}$ & .005 & 1 & .941 & & \\
\hline Likelihood Ratio & .021 & 1 & .886 & & \\
\hline Fisher's Exact Test & & & & & \\
\hline Linear-by-Linear Association & .021 & 1 & .886 & & \\
\hline $\mathrm{N}$ of Valid Cases & 939 & & & & \\
\hline
\end{tabular}

a. 0 cells $(0.0 \%)$ have expected count less than 5 . The minimum expected count is 126.02 .

b. Computed only for a $2 \times 2$ table

Table 3: Chi-Square tests

\begin{tabular}{|ll|r|r|}
\hline & & \multicolumn{1}{|c|}{ Value } & \multicolumn{1}{c|}{ Approx. Sig. } \\
\hline \multirow{2}{*}{ Nominal by Nominal } & Phi & .005 & .886 \\
& Cramer's V & .005 & .886 \\
N of Valid Cases & & 939 & \\
\hline
\end{tabular}

a. Not assuming the null hypothesis.

b. Using the asymptotic standard error assuming the null hypothesis.

Table 4: Symmetric measures

Based on the above table, (sig $=0 / 886>0.05)$ Chi-Square test showed a significant relationship between questioning and the physician's gender.

$\int \mathrm{H} 0$ : There is a relationship between questioning and the physician's experience

H1: There is not a relationship between questioning and the physician's experience

Count

\begin{tabular}{|ll|r|r|r|}
\hline & & \multicolumn{2}{|c|}{ Exper } & \multicolumn{2}{c|}{ Total } \\
\cline { 3 - 4 } & & Experienced & \multicolumn{1}{|c|}{ Inexperienced } & \\
\hline \multirow{2}{*}{ questioning } & No & 294 & 300 & 594 \\
\multirow{2}{*}{ Total } & Yes & 189 & 156 & 345 \\
& & 483 & 456 & 939 \\
\hline
\end{tabular}

Table 5: Questioning * exper crosstabulation 


\begin{tabular}{|l|r|r|r|r|r|}
\hline & \multicolumn{1}{|c|}{ Value } & \multicolumn{1}{c|}{ df } & $\begin{array}{c}\text { Asymp. Sig. } \\
\text { (2-sided) }\end{array}$ & $\begin{array}{c}\text { Exact Sig. } \\
\text { (2-sided) }\end{array}$ & $\begin{array}{c}\text { Exact Sig. } \\
\text { (1-sided) }\end{array}$ \\
\hline Pearson Chi-Square & $2.443^{\mathrm{a}}$ & 1 & .118 & & \\
Continuity Correction $^{\mathrm{b}}$ & 2.236 & 1 & .135 & & \\
Likelihood Ratio $^{\text {Fisher's Exact Test }}$ & 2.445 & 1 & .118 & & \\
Linear-by-Linear Association & 2.440 & 1 & .118 & & .067 \\
N of Valid Cases & 939 & & & & \\
\hline
\end{tabular}

a. 0 cells $(0.0 \%)$ have expected count less than 5 . The minimum expected count is 167.54 .

b. Computed only for a $2 \times 2$ table

Table 6: Chi-Square tests

\begin{tabular}{|l|l|r|r|}
\hline & & \multicolumn{1}{|c|}{ Value } & \multicolumn{1}{c|}{ Approx. Sig. } \\
\hline \multirow{3}{*}{ Nominal by Nominal } & Phi & -.051 & .118 \\
& & .051 & .118 \\
N of Valid Cases & Cramer's V & 939 & \\
\hline
\end{tabular}

a. Not assuming the null hypothesis.

b. Using the asymptotic standard error assuming the null hypothesis.

Table 7: Symmetric measures

As shown in Table 7, (sig=0/118 $>0.05)$ Chi-Square test showed a significant relationship between questioning and the physician's experience. This result is compatible with Kunsmann (2005) and Černý (2010).

$\int \mathrm{H} 0$ : There is a relationship between interruption and the physician's gender

H1: There is not a relationship between interruption and the physician's gender

Count

\begin{tabular}{|ll|r|r|r|}
\hline & & \multicolumn{2}{|c|}{ Gender } & \multirow{2}{*}{ Total } \\
\cline { 3 - 4 } & & male & \multicolumn{1}{|c|}{ female } & \\
\hline \multirow{2}{*}{ Interruption } & No & 320 & 548 & 868 \\
Total & Yes & 23 & 48 & 71 \\
& & 343 & 596 & 939 \\
\hline
\end{tabular}

Table 8: Interruption * gender crosstabulation 


\begin{tabular}{|c|c|c|c|c|c|}
\hline & Value & df & $\begin{array}{l}\text { Asymp. Sig. } \\
\text { (2-sided) }\end{array}$ & $\begin{array}{l}\text { Exact Sig. } \\
\text { (2-sided) }\end{array}$ & $\begin{array}{l}\text { Exact Sig. } \\
\text { (1-sided) }\end{array}$ \\
\hline Pearson Chi-Square & $.566^{\mathrm{a}}$ & 1 & .452 & \multirow{6}{*}{.522} & \multirow{6}{*}{.268} \\
\hline Continuity Correction $^{\mathrm{b}}$ & .390 & 1 & .532 & & \\
\hline Likelihood Ratio & .575 & 1 & .448 & & \\
\hline Fisher's Exact Test & & & & & \\
\hline Linear-by-Linear Association & .566 & 1 & .452 & & \\
\hline $\mathrm{N}$ of Valid Cases & 939 & & & & \\
\hline
\end{tabular}

a. 0 cells $(0.0 \%)$ have expected count less than 5 . The minimum expected count is 25.94 .

b. Computed only for a $2 \times 2$ table

Table 9: Chi-Square tests

\begin{tabular}{|l|l|r|r|}
\hline & & \multicolumn{1}{|c|}{ Value } & \multicolumn{1}{c|}{ Approx. Sig. } \\
\hline \multirow{3}{*}{ Nominal by Nominal } & Phi & .025 & .452 \\
& & .025 & .452 \\
N of Valid Cases & Cramer's V & 939 & \\
\hline
\end{tabular}

a. Not assuming the null hypothesis.

b. Using the asymptotic standard error assuming the null hypothesis.

Table 10: Symmetric measures

As Table 10 shows, $($ sig $=0 / 452>0.05)$ Chi-Square test showed a significant relationship between interruption and the physician's gender.

H0: There is a relationship between interruption and the physician's experience H1: There is not a relationship between interruption and the physician's experience

\begin{tabular}{|c|c|c|c|c|c|c|}
\hline & \multicolumn{6}{|c|}{ Cases } \\
\hline & \multicolumn{2}{|c|}{ Valid } & \multicolumn{2}{|c|}{ Missing } & \multicolumn{2}{|c|}{ Total } \\
\hline & $\mathbf{N}$ & Percent & $\mathbf{N}$ & Percent & $\mathbf{N}$ & Percent \\
\hline interruption * Exper & 939 & $100.0 \%$ & 0 & $0.0 \%$ & 939 & $100.0 \%$ \\
\hline
\end{tabular}

Table 11: Case processing summary

Count

\begin{tabular}{|ll|r|r|r|}
\hline & & \multicolumn{2}{|c|}{ Exper } & \multirow{2}{*}{ Total } \\
\cline { 3 - 4 } & & Inexperienced & Experienced & \\
\hline \multirow{2}{*}{ Interruption } & No & 443 & 425 & 868 \\
Total & Yes & 40 & 31 & 71 \\
\hline
\end{tabular}

Table 12: Interruption * exper crosstabulation 


\begin{tabular}{|c|c|c|c|c|c|}
\hline & Value & df & $\begin{array}{l}\text { Asymp. Sig. } \\
\text { (2-sided) }\end{array}$ & $\begin{array}{l}\text { Exact Sig. } \\
\text { (2-sided) }\end{array}$ & $\begin{array}{l}\text { Exact Sig. } \\
\text { (1-sided) }\end{array}$ \\
\hline Pearson Chi-Square & $.738^{\mathrm{a}}$ & 1 & .390 & \multirow{6}{*}{.459} & \multirow{6}{*}{.231} \\
\hline Continuity Correction ${ }^{\mathrm{b}}$ & .541 & 1 & .462 & & \\
\hline Likelihood Ratio & .741 & 1 & .389 & & \\
\hline Fisher's Exact Test & & & & & \\
\hline Linear-by-Linear Association & .738 & 1 & .390 & & \\
\hline $\mathrm{N}$ of Valid Cases & 939 & & & & \\
\hline
\end{tabular}

a. 0 cells $(0.0 \%)$ have expected count less than 5 . The minimum expected count is 34.48 .

b. Computed only for a $2 \times 2$ table

Table 13: Chi-Square tests

\begin{tabular}{|l|l|r|r|}
\hline & & \multicolumn{1}{|c|}{ Value } & \multicolumn{1}{c|}{ Approx. Sig. } \\
\hline \multirow{3}{*}{ Nominal by Nominal } & Phi & .028 & .390 \\
& & .028 & .390 \\
N of Valid Cases & Cramer's V & & 939 \\
\hline
\end{tabular}

a. Not assuming the null hypothesis.

b. Using the asymptotic standard error assuming the null hypothesis.

Table 14: Symmetric measures

As shown in Table 14, (sig=0/390>0.05) Chi-Square test showed a significant relationship between interruption and the physician's experience.

$\int \mathrm{H} 0$ : There is a relationship between directive statement and the physician's gender

H1: There is not a relationship between directive statement and the physician's gender

\begin{tabular}{|c|c|c|c|c|c|c|}
\hline & \multicolumn{6}{|c|}{ Cases } \\
\hline & \multicolumn{2}{|c|}{ Valid } & \multicolumn{2}{|c|}{ Missing } & \multicolumn{2}{|c|}{ Total } \\
\hline & $\mathbf{N}$ & Percent & $\mathbf{N}$ & Percent & $\mathbf{N}$ & Percent \\
\hline directive voice * Gender & 939 & $100.0 \%$ & 0 & $0.0 \%$ & 939 & $100.0 \%$ \\
\hline
\end{tabular}

Table 15: Case Processing Summary

Count

\begin{tabular}{|ll|r|r|r|}
\hline \multirow{2}{*}{} & & \multicolumn{2}{|c|}{ Gender } & \multirow{2}{*}{ Total } \\
\cline { 3 - 4 } & \multicolumn{2}{|c|}{ male } & \multicolumn{1}{|c|}{ female } & \\
\hline \multirow{2}{*}{ directive_statement } & No & 274 & 493 & 767 \\
\multirow{2}{*}{ Total } & Yes & 69 & 103 & 172 \\
& & 343 & 596 & 939 \\
\hline
\end{tabular}

Table 16: Directive statements * gender crosstabulation 


\begin{tabular}{|l|r|r|r|r|r|}
\hline & \multicolumn{1}{|c|}{ Value } & \multicolumn{1}{|c|}{ df } & \multicolumn{1}{c|}{$\begin{array}{c}\text { Asymp. Sig. } \\
\text { (2-sided) }\end{array}$} & $\begin{array}{c}\text { Exact Sig. } \\
\text { (2-sided) }\end{array}$ & $\begin{array}{c}\text { Exact Sig. } \\
\text { (1-sided) }\end{array}$ \\
\hline Pearson Chi-Square & $1.169^{\mathrm{a}}$ & 1 & .280 & & \\
Continuity Correction $^{\mathrm{b}}$ & .987 & 1 & .320 & & \\
Likelihood Ratio $^{1.158}$ & 1 & .282 & & \\
Fisher's Exact Test & & & & .294 & .160 \\
Linear-by-Linear Association & 1.168 & 1 & .282 & & \\
N of Valid Cases & 939 & & & & \\
\hline
\end{tabular}

a. 0 cells $(0.0 \%)$ have expected count less than 5 . The minimum expected count is 62.83 .

b. Computed only for a $2 \times 2$ table

Table 17: Chi-Square tests

\begin{tabular}{|l|l|r|r|}
\hline & & \multicolumn{1}{|c|}{ Value } & \multicolumn{1}{c|}{ Approx. Sig. } \\
\hline Nominal by Nominal & Phi & .035 & .280 \\
& Cramer's V & .035 & .280 \\
N of Valid Cases & & 939 & \\
\hline
\end{tabular}

a. Not assuming the null hypothesis.

b. Using the asymptotic standard error assuming the null hypothesis.

Table 18: Symmetric measures

Based on Table 18, (sig=0/280 $>0.05)$ Chi-Square test showed a significant relationship between directive statements and the physician's gender. This result is in conformity with Ohtaki et al. (2003: 278) and Gyuró (2014: 4).

$\int \mathrm{H} 0$ : There is a relationship between directive statement and experience

H1: There is not relationship between directive statement and experience

Count

\begin{tabular}{|ll|r|r|r|}
\hline & & \multicolumn{2}{|c|}{ Exper } & \multirow{2}{*}{ Total } \\
\cline { 3 - 4 } & & Inexperienced & Experienced & \\
\hline \multirow{2}{*}{ directive_voice } & No & 377 & 390 & 767 \\
& Yes & 106 & 66 & 172 \\
Total & & 483 & 456 & 939 \\
\hline
\end{tabular}

Table 19: Directive statement * exper crosstabulation 


\begin{tabular}{|l|r|r|r|r|r|}
\hline & \multicolumn{1}{|c|}{ Value } & \multicolumn{1}{c|}{ df } & \multicolumn{1}{c|}{$\begin{array}{c}\text { Asymp. Sig. } \\
\text { (2-sided) }\end{array}$} & $\begin{array}{c}\text { Exact Sig. } \\
\text { (2-sided) }\end{array}$ & $\begin{array}{c}\text { Exact Sig. } \\
\text { (1-sided) }\end{array}$ \\
\hline Pearson Chi-Square & $2.071 \mathrm{a}$ & 1 & .093 & & \\
Continuity Correctionb & 8.261 & 1 & .004 & & \\
Likelihood Ratio & 2.071 & 1 & .093 & & .099 \\
Fisher's Exact Test & & & & & \\
Linear-by-Linear Association & 2.071 & 1 & .093 & & \\
N of Valid Cases & 939 & & & & \\
\hline
\end{tabular}

a. 0 cells $(0.0 \%)$ have expected count less than 5 . The minimum expected count is 83.53 .

b. Computed only for a $2 \times 2$ table

Table 20: Chi-Square tests

\begin{tabular}{|l|l|r|r|}
\hline & & \multicolumn{1}{|c|}{ Value } & \multicolumn{1}{c|}{ Approx. Sig. } \\
\hline \multirow{3}{*}{ Nominal by Nominal } & Phi & .097 & .093 \\
& & .097 & .093 \\
N of Valid Cases & Cramer's V & 939 & \\
\hline
\end{tabular}

a. Not assuming the null hypothesis.

b. Using the asymptotic standard error assuming the null hypothesis.

Table 21: Symmetric measures

Based on the above table, (sig=0/093 $>0.05)$ Chi-Square test showed a significant relationship between directives and the physician's experience.

$\int \mathrm{H} 0$ : There is a relationship between tag questions and the physician's gender H1: There is not a relationship between tag questions and the physician's gender

Count

\begin{tabular}{|ll|r|r|r|}
\hline & & \multicolumn{2}{|c|}{ Gender } & \multirow{2}{*}{ Total } \\
\cline { 3 - 4 } & & male & female & \\
\hline \multirow{2}{*}{ Tag_Question } & No & 115 & 276 & 391 \\
Total & Yes & 300 & 248 & 548 \\
& & 415 & 524 & 939 \\
\hline
\end{tabular}

Table 22: Tag question * gender crosstabulation 


\begin{tabular}{|l|r|r|r|r|r|}
\hline & \multicolumn{1}{|c|}{ Value } & \multicolumn{1}{c|}{ df } & $\begin{array}{c}\text { Asymp. Sig. } \\
\text { (2-sided) }\end{array}$ & $\begin{array}{c}\text { Exact Sig. } \\
\text { (2-sided) }\end{array}$ & $\begin{array}{c}\text { Exact Sig. } \\
\text { (1-sided) }\end{array}$ \\
\hline Pearson Chi-Square & $.015^{\mathrm{a}}$ & 1 & .251 & & \\
Continuity Correction & .005 & 1 & .003 & & \\
Likelihood Ratio & .015 & 1 & .251 & & \\
Fisher's Exact Test & & & & .304 & .175 \\
Linear-by-Linear Association & .015 & 1 & .251 & & \\
N of Valid Cases & 939 & & & & \\
\hline
\end{tabular}

a. 0 cells $(0.0 \%)$ have expected count less than 5 . The minimum expected count is 6.49 .

b. Computed only for a $2 \times 2$ table

Table 23: Chi-Square tests

\begin{tabular}{|l|l|r|r|}
\hline & & \multicolumn{1}{|c|}{ Value } & \multicolumn{1}{c|}{ Approx. Sig. } \\
\hline \multirow{3}{*}{ Nominal by Nominal } & Phi & .005 & .251 \\
& & .005 & .251 \\
N of Valid Cases & Cramer's V & 939 & \\
\hline
\end{tabular}

a. Not assuming the null hypothesis.

b. Using the asymptotic standard error assuming the null hypothesis.

Table 24: Symmetric measures

Based on Table 24, (sig=0/251>0.05) Chi-Square test showed a significant relationship between tag questions and the physician's gender.

H0: There is a relationship between tag questions and the physician's experience

H1: There is not a relationship between tag questions and the physician's experience

Count

\begin{tabular}{|ll|r|r|r|}
\hline & & \multicolumn{2}{|c|}{ Exper } & \multirow{2}{*}{ Total } \\
\cline { 3 - 4 } & & Inexperienced & Experienced & \\
\hline \multirow{2}{*}{ Tag_Question } & No & 300 & 306 & 606 \\
Total & Yes & 121 & 212 & 333 \\
\hline
\end{tabular}

Table 25: Tag question * exper crosstabulation 


\begin{tabular}{|c|c|c|c|c|c|}
\hline & Value & df & $\begin{array}{l}\text { Asymp. Sig. } \\
\text { (2-sided) }\end{array}$ & $\begin{array}{l}\text { Exact Sig. } \\
\text { (2-sided) }\end{array}$ & $\begin{array}{l}\text { Exact Sig. } \\
\text { (1-sided) }\end{array}$ \\
\hline Pearson Chi-Square & $.020^{\mathrm{a}}$ & 1 & .798 & \multirow{6}{*}{.934} & \multirow{6}{*}{.451} \\
\hline Continuity Correction ${ }^{\mathrm{b}}$ & .005 & 1 & .841 & & \\
\hline Likelihood Ratio & .020 & 1 & .798 & & \\
\hline Fisher's Exact Test & & & & & \\
\hline Linear-by-Linear Association & .020 & 1 & .798 & & \\
\hline $\mathrm{N}$ of Valid Cases & 939 & & & & \\
\hline
\end{tabular}

a. 0 cells $(0.0 \%)$ have expected count less than 5 . The minimum expected count is 8.63.

b. Computed only for a $2 \times 2$ table

Table 26: Chi-Square tests

\begin{tabular}{|l|l|r|r|}
\hline & & \multicolumn{1}{|c|}{ Value } & \multicolumn{1}{c|}{ Approx. Sig. } \\
\hline \multirow{2}{*}{ Nominal by Nominal } & Phi & .025 & .798 \\
& & .025 & .798 \\
N of Valid Cases & Cramer's V & 939 & \\
\hline
\end{tabular}

a. Not assuming the null hypothesis.

b. Using the asymptotic standard error assuming the null hypothesis.

Table 27: Symmetric measures

As shown in Table 27, $($ sig $=0 / 798>0.05)$ Chi-Square test showed a significant relationship between tag questions and the physician's experience. This result is in accordance with Heritage (2010).

This study investigated the effects of the physician's gender and experience on the physician-patient interactions. Women and men differed in the way they exerted power. The gender of the patient in this study was not a significant variable.

Based on the results reported above, Table 1 revealed that the female and inexperienced physicians tended to control consultations by questioning more than male and experienced physicians; it was also female and inexperienced physicians that tended to use interruption and directives and tag questions more than male and experienced physicians.

The first strategy was questioning that manifested power and asymmetry on the doctor-patient interaction. The above tables of Chi-Square test showed its relationship with the physician's gender and experience.

The second strategy, illustrated in Example 2, was employed by doctors in order to elicit either repairs of patients' preceding utterance or repeats for confirmation of what the patient had suggested. Our results indicated that physicians sometimes interrupted the patient's additional explanations by 
saying okay, so they ignored the patient's reactions and cut off any elaborations. The analysis manifested the relationship between the interruptions and the physician's gender and experience. The female physicians interrupted patients more frequently than the male physicians.

The third strategy was the use of directives. Our data and Example 3 indicated that the physicians used directives to assure their patients about diagnosis and treatment. At the end, the physicians formulated their advice explicitly as a direction and proposal, sometimes the patient reacted minimally to the physician's explanation, starting a further complaint and description. The above tables showed the frequency of directive strategy and its relationship with the physician' gender and experience.

The fourth strategy was that the physicians used tag questions in their consultations so that patients would affirm the physicians' comments and avoid questioning, as in Example 4. This strategy also showed women's empathy. It caused the patient to avoid asking more questions about his/her condition. Our data indicated a high frequency of tag questions. Women use question tags more often to express uncertainty while men use them largely to facilitate communication. Tag questions request information or ask for confirmation of the information.

\section{Conclusion}

Our study is consistent with previous research in other parts of the world that found the asymmetrical pattern of physician-patient interaction. In this study, we hypothesized that four power strategies were applied in Iranian medical interactions. Our research verified that physicians controlled medical consultations by asking more questions, interruption, directive statements and tag questions and indicated that physicians' power and knowledge were reflected in their interactions.

To sum up, there are four main findings to the research questions. The analysis of the data revealed that all power strategies were applied in Iranian physicianpatient interactions. Our study concluded that there was a significant relationship between power strategies and the physicians' gender and experience. First, the results revealed that there was a significant relationship between questioning and the physicians' gender and experience, and that female and inexperienced physicians tend to control consultations more by questioning than male and experienced physicians.

Second, there was a significant relationship between interruption and the physicians' gender and experience. Female and inexperienced physicians 
tended to control consultations more by interruption than male and experienced physicians.

Third, the results revealed there was a significant relationship between directive statements and the physicians' gender and experience. Female and inexperienced physicians tended to control consultations more by directive statement than male and experienced physicians.

Finally, our data confirmed that there was a significant relationship between tag questions and the physicians' gender and experience. Female and experienced physicians tended to control consultations more by tag questions than male and inexperienced physicians.

Our study alongside the work being done elsewhere indicated that Persian physician-patient interactions are asymmetrical. Our data proved that female and inexperienced physicians showed higher level of dominance and control over their consultations than male physicians by using questions, interruption, directive statements and tag questions.

\section{Limitations}

The limitation of the study in this research was related to the limitation of collecting the data and physicians who participated in this research.

\section{Suggestions for further research}

This detailed empirical examination of physicians and patients' interaction provides insights into the asymmetrical talk of Persian medical consultations. In addition to providing numbers and a method for comparison, such studies could take into account variables other than gender and experience, for example, age, education, and both the physician's and patient's gender.

\section{Acknowledgement}

The authors would like to thank the physicians and patients for participating in this study. We are indebted to all the receptionists in the Modares and Farhangiyan clinics and Ali Ibn Abi Taleb hospital and manager of university of Medical Sience of Rafsanjan whose support made this study possible. The authors would like to thank Dr Babak Bakhtar, Dr Abbas Fatehi, Dr Parvane Hatami, Dr Afshin Tahmasbi, Dr Masoud Rademan, Dr Yousef Taghavi, Dr Mozhde Khatami, and Dr Maryam Karimi Fard and those who want to be anonymous. 


\section{References}

Barnet, J. M. (2006) The Function of Norms in Doctor-Patient Communication, (Doctoral dissertation). The Pennsylvania State University: College of the Liberal Arts, online document. <https://etda.libraries.psu.edu/files/final submissions/3133>.

Černý, M. (2007) 'On the function of speech acts in doctor-patient communication.' Linguistica online. Online document.< http://www.phil.muni.cz/linguistica/art/cerny/ cer-001>.

Černý, M. (2010) Interruptions and Overlaps in Doctor-Patient Communication Revisited. Ostrava: Ostravská univerzita.

Cirillo, L. (2005) The Interactional Organization of Talk in Naturopathic Interviews (Doctoral dissertation). Federico: University of Napoli. <http://www.fedoa.unina. it/880/1/Cirillo-Letizia_Tesi.pdf $>$.

Gyuró, M. (2014) 'Interviewing in the medical context: Questions, answers, assessments: An interdisciplinary approach.' Topics in Linguistics 13, Online document: <https:// doi.org/10.2478/topling-2014-0005>.

Harres, A. (1998) “"But basically you're feeling well, are you?" Tag questions in medical consultations.' Health Communication 10/2, 111-123.

Hashemi, M. (2003) Reflecting the Power Relationship in Persian Doctor and Patient Discourse (Master's thesis). Tehran: Allameh Tabatabai University.

Heritage, J. (2010) 'Questioning in medicine.' In: Freed, A. and Ehrlich, S. (eds) “Why Do You Ask?" The Function of Questions in Institutional Discourse. New York: Oxford University Press. 42-68.

Jefferson, L., Bloor, K., Briks, Y., Hewitt, C. and Bland, M. (2013) 'Effect of physicians' gender on communication and consultation length: A systematic review and metaanalysis.' Health Serv Res Policy 18/4, 242-248.

Kunsmann, P. (2005) 'Gender, status and power in discourse behavior men and women.' Linguistik online 5, 1/00. Freie: University of Berlin. <http://www.linguistikonline. com/1 00/ KUNSMANN.HTM $>$.

Li, H. Z., Desroches, N., Yum, O. K., Koehn, C. and Deagle, G. (2007) 'Asymmetrical talk between physicians and patients: A quantitative discourse analysis.' Canadian Journal of Communication 32, 417-433.

Li, H. Z., Krysko, M., Desroches, N. G. and Deagle, G. (2004) 'Re-conceptualizing interruptions in physician-patient interview: Co-operative and intrusive.' Communication and Medicine: An Interdisciplinary Journal of Healthcare, Ethics and Society 1, 145-157.

Ohtaki, S., Ohtaki, T. and Fetters, M. D. (2003) 'Doctor-patient communication: A comparison of the USA and JAPAN.' Family Practice 20, 276-282.

Rhoades, D. R., McFarland, K. F., Finch, W. H. and Johnson, A. O. (2001) 'Speaking and interruptions during primary care office visits.' University of South Carolina: Family Medicine 33/7, 528-532.

Roter, D. L., Hall, J. A. and Aoki, Y. (2002) 'Physician gender effects in medical communication: A meta-analytic review.' America: JAMA 288/6, 756-764.

Schmidmast, M. (2004) 'Dominance and gender in the physician-patient interaction.' Elsiver 1, 354-358.

Simpson, P. and Mayr, A. (2010) Language and Power. New York, London: Routledge.

Thompson, G. (2009) 'Just checking, questions and social roles.' In: Shiro, M., Bentivoglio, P. and Ehrlich, F. (eds) Haciendo Discurso: Homenaje an Adriana Bolivar (Talking Discourse: In Honour of Adriana Bolivar). Caracas: Universidad Central de Venezuela. 141-156. 
Woods, N. (2006) Describing Discourse. London: Hodder Arnold.

Yule, G. (2010) The Study of Language. $4^{\text {th }}$ ed. Cambridge: Cambridge University Press.

Fariba Ramazani Sarbandi is Part-Time Instructor at the Department of General Linguistics and English Language and Literature, Vali-Asr University, Rafsanjan, Iran. She is a M.A. Graduate Student of General linguistics, University of Sistan and Baluchestan, Zahedan, Iran. She has been teaching different courses in language and linguistics at Vali-Asr University, Rafsanjan, Iran since 2013. Her field of interest includes discourse analysis, critical discourse analysis, pragmatics and cognitive linguistics.

Address: Fariba Ramazani Sarbandi, Department of General Linguistics and English Language and Literature, Humanities Faculty, 22 Bahman Bolvar, Valie-Asr University, Rafsanjan, Iran. [e-mail: faribaramezani53@yahoo.com]

Giti Taki is Assistant Professor of Linguistics at Sistan \& Baluchestan University in Zahedan. She has been teaching different courses in language and linguistics since 1992 and her publications have appeared in several national journals including Journal of Linguistics, Journal of Language and Linguistics and Journal of Linguistic Queries. Her main areas of research include pragmatics and discourse analysis, focusing on critical discourse analysis.

Address: Giti Taki, English Department, Humanities Faculty, Sistan \& Baluchestan University, Zahedan, Iran. [e-mail: giti_taki2020@yahoo.com]

Pakzad Yousefian is Assistant Professor of Linguistics at Sistan \& Baluchestan University in Zahedan. He has been teaching English Language and Linguistics since 1990. His publications have appeared in several national journals and international conferences. His main areas of research include typology and dialectology, focusing on Persian and Baluchi.

Address: Pakzad Yousefian, English Department, Humanities Faculty, Sistan \& Baluchestan University, Zahedan, Iran. [e-mail: pakzady@gmail.com]

Mohamad Reza Farangi is $\mathrm{PhD}$ student in Applied Linguistics at Shiraz University. He has published in several national and international journals. His fields of interest are discourse studies, language testing and teacher education.

Address: Mohamad Reza Farangi, PhD student, Shiraz University, Shiraz, Iran. [e-mail: Mohamadrezafarangi@gmail.com] 